\title{
Influence of fibromucosa height and loading on the stress distribution of a total prosthesis: a finite element analysis
}

Influência da altura da fibromucosa e carregamento na distribuição de tensões de prótese total: análise por elementos finitos

Tarcisio José de Arruda PAES-JUNIOR ${ }^{1}$, João Paulo Mendes TRIBST ${ }^{1}$, Amanda Maria de Oliveira DAL PIVA ${ }^{1}$, Viviane Maria Gonçalves de FIGUEIREDO ${ }^{2}$, Alexandre Luiz Souto BORGES ${ }^{1}$, Cristiane Mayumi INAGATI ${ }^{1}$

1- Department of Dental Materials and Prosthetics, São Paulo State University (UNESP), Institute of Science and Technology, São José dos Campos Dental School, São José dos Campos, Brazil.

2- Department of Prosthesis and Oral-Facial Surgery, Pernambuco Federal University (UFPE). Recife, Pernambuco, Brazil.

\section{ABSTRACT}

Purpose: To evaluate the effect of fibromucosa height on the stress distribution and displacement of mandibular total prostheses during posterior unilateral load, posterior bilateral load and anterior guidance using the finite element analysis (FEA). Material and methods: 3D virtual models were made to simulate the stress generated during different mandibular movements in a total prosthesis. The contacts were simulated according to the physiology, being considered perfectly bonded between cortical and medullar bones; and between cortical bone and mucosa. Non-linear frictional contact was used for the total prosthesis base and fibromucosa, allowing the prosthesis to slide over the tissue. The cortical bone base was fixed and the $100 \mathrm{~N}$ load was applied as unilateral load, posterior bilateral load and anterior guidance simulation. The required results were for maximum principal stress $(\mathrm{MPa})$, microstrain $(\mathrm{mm} / \mathrm{mm})$ and total displacement $(\mathrm{mm})$. The numerical results were converted into colorimetric maps and arranged according to corresponding scales. Results: The stress generated in all situations was directly proportional to the fibromucosa height. The maximum principal stress results demonstrated greater magnitude for anterior guidance, posterior unilateral and posterior bilateral, respectively. Only posterior unilateral load demonstrated an increase in bone microstrain, regardless of the fibromucosa height. Prosthesis displacement was lower under posterior bilateral loading. Conclusion: Posterior bilateral loading is indicated for total prosthesis because it allows lower prosthesis displacement, lower stress concentration at the base of the prosthesis and less bone microstrain.

\section{KEYWORDS}

Finite element analysis; Occlusion; Total prosthesis.

\section{RESUMO}

Objetivo: Avaliar o efeito da altura da fibromucosa na distribuição de tensões e deslocamento das próteses totais mandibulares durante a carga unilateral posterior, carga bilateral posterior e orientação anterior usando a análise por elementos finitos (FEA). Material e métodos: Modelos virtuais 3D foram confeccionados para simular a tensão gerada durante diferentes movimentos mandibulares em uma prótese total. Os contatos foram simulados de acordo com a fisiologia, sendo considerados perfeitamente unidos entre os ossos corticais e medulares; e entre o osso cortical e a mucosa. O contato friccional não linear foi utilizado entre a base total da prótese e a fibromucosa, permitindo que a prótese deslizasse sobre o tecido. A base do osso cortical foi fixada e a carga de $100 \mathrm{~N}$ aplicada como carga unilateral, carga bilateral posterior e simulação de guia incisiva anterior. Os resultados foram calculados em tensão máxima principal (MPa), microdeformação (mm/ $\mathrm{mm}$ ) e deslocamento total (mm). Os resultados numéricos foram convertidos em mapas colorimétricos e organizados de acordo com as escalas correspondentes. Resultados: A tensão gerada em todas as situações foi diretamente proporcional à altura da fibromucosa. Os resultados de tensão máxima principal demonstraram maior magnitude durante a carga anterior, posterior unilateral e posterior bilateral, respectivamente. Apenas a carga unilateral posterior demonstrou aumento da microdeformação óssea, independente da altura da fibromucosa. O deslocamento da prótese foi menor sob carga bilateral posterior. Conclusão: A carga bilateral posterior é indicada para prótese total, pois permite menor deslocamento da prótese, menor concentração de tensões na base da prótese e menor microdeformação óssea.

\section{PALAVRAS-CHAVE}

Análise de elementos finitos; Oclusão; Prótese total. 


\section{INTRODUCTION}

$\mathrm{D}$ ue to a better control of oral hygiene, many people currently have their natural teeth until old age, however, in some cases tooth loss is inevitable [1-2]. With the increase of older people population, practitioners should focus on maintaining high quality rehabilitations [2-3].

The use of total prostheses for edentulous patients is the treatment of choice to improve masticatory capacity and their oral health, restoring aesthetics, and patient satisfaction in an accessible manner [4-5]. However, adapting the mandibular prosthesis is more difficult than the upper one, since bone remodeling of the lower arch mainly occurs in the vertical direction, thus hindering functioning of the prosthesis that rests on the residual border [6]. A suitable occlusal surface is necessary in order to obtain good prosthesis retention and stability, as well as to prepare occlusal adjustments that correctly guide the masticatory loads [7].

There are several forms of occlusion in edentulous patients, in which bilateral balanced occlusion is the most used, and seeks to provide better mastigatory performance and improve the patient quality of life [8-9]. Excursive movements are avoided as in the anterior guidance, in which the posterior teeth perform horizontal excursive movements and vertical overlap of the jaw [910]; as well as, the unilateral loadings, where the teeth are contacted in a disocclusion pattern reducing the stability [6].

To evaluate the retention and the stability of the total prosthesis, in live methods or in silico evaluation can be used to accurately assess the retentive force of the total prosthesis $[5,11]$ and this is true also regardless to construction methods [12-13].The advantages of an in silico test as finite element analysis (FEA), are the possibility to calculate mechanical responses impossible to be measured in experimental tests, the ability to isolate physical data, and the ease in which conditions can be defined in comparison with other mechanical tests [11]. In addition, it is important to note that several studies use FEA to evaluate the stress and strain in the prosthesis and the fibromucosa $[11,14-16]$. Although it is a theoretical study, FEA provides precise results by dividing a complex model into smaller elements, simulating boundary conditions and physical properties of the tested subject [11].

Another factor that can influence planning and execution of a total prosthesis is the resilience and amount of fibromucosa of each patient, which modifies the molding technique and prognosis for each case. Despite the evidence produced to date, there are no studies explaining how the fibromucosa height influences the biomechanical response of the masticatory load transmission. The purpose of this study was to evaluate the effect of occlusion, of the fibromucosa height on the stress distribution, microstrain and displacement of a mandibular total prosthesis during posterior unilateral load, posterior bilateral load and anterior guidance using finite element analysis (FEA). The tested null hypothesis was that the fibromucosa height and loading did not influence the prosthesis biomechanical response.

\section{MATERIAL AND METHODS}

\section{Finite element Analysis (FEA)}

\section{Three-dimensional modeling}

$3 \mathrm{D}$ virtual models were developed as a function of different fibromucosa heights in inferior full-arch total prosthesis during posterior unilateral, posterior bilateral load and anterior guidance loading. A mandibular full-arch prosthesis and an edentulous dental manikin were scanned by a Ceramill Map 300 Scanner (Amann Girrbach, Austria) to generate a STL (Stereolithography) file, which was exported to a CAD (Computer Aided Design) software, (Rhinoceros 5.0, McNeel North America - Seatlle - USA), in which the models were produced within the BioCAD protocol [17]. In this phase, 
the models were generated from the lines on the STL image with their anatomical characteristics to generate surfaces. The surfaces were joined in solids to delimit the volumetric structures and then, exported in STEP format (Standard for the Exchange of Product Model Data) to the analysis software (Ansys 17.2 ANSYS, Inc. Southpointe, Canonsburg, USA). Three different models were created according to fibromucosa height (Figure 1). In figure 1 , it is possible to observe the greater amount of bone resorption, the greater fibromucosa tissue thickness.

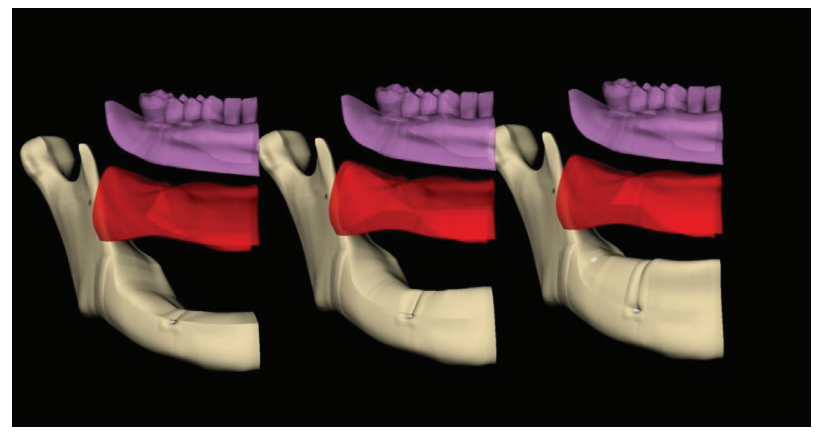

Figure 1-3D model simulating the base of the jaw, different mucosa height and the total prosthesis. a) Thick fibromucosa; b) Medium fibromucosa; c) Thin fibromucosa.

\section{Pre-processing}

The mesh convergence test $(10 \%)$ was used to subdivide the complex geometry into a finite number of elements. The contacts were simulated according to physiology, with no separation between cortical bone and medullary bone, or cortical bone and mucosa. Non-linear "rough" contact was used for the total prosthesis base and the fibromucosa, allowing the prosthesis to slide over the tissue but not separate (Figure 1). The contact between resin teeth and the total prosthesis base was considered as bonded due to the chemical bonding between these structures made of the same polymer. Each material was considered isotropic, elastic and homogeneous. The mechanical properties were reported based on the literature (Table I) [18-19]. The boundary conditions were: fixation at the jaw base, unilateral occlusion simulation with axial loading on the occlusal face of the first lower right molar $\left(90^{\circ}, 100 \mathrm{~N}\right)$, bilateral axial loading on the occlusal face of both lower first molars $\left(90^{\circ}, 100 \mathrm{~N}\right)$ and anterior guidance simulation with oblique loading on the incisal face of the lower central incisors $\left(45^{\circ}, 100 \mathrm{~N}\right.$ ) (Figure 2).
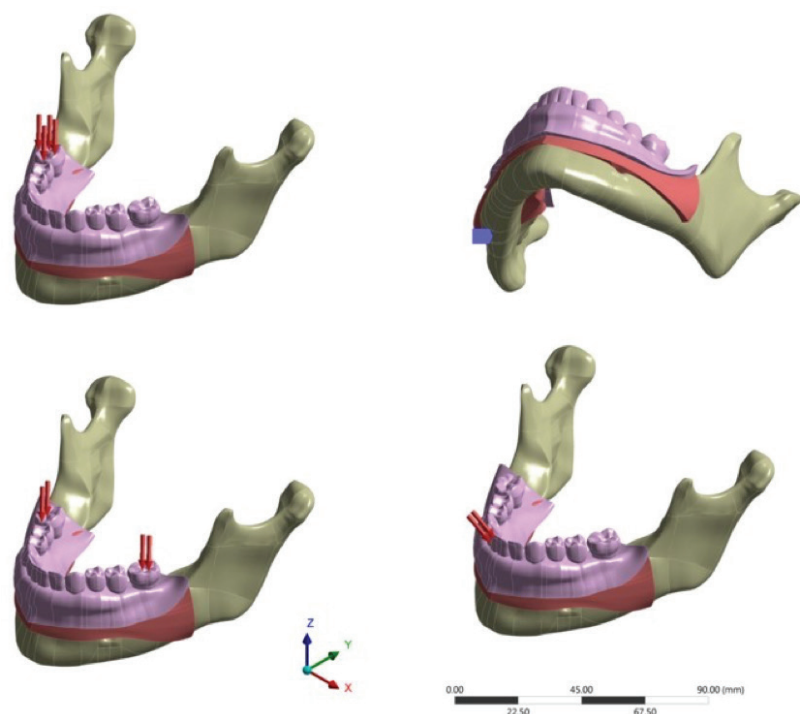

Figure 2 - Simulation of masticatory load according to the soft tissue height (From left to right: thick, medium and thin) and different loads (Columns): a) Unilateral posterior loading; b) Bilateral posterior loading; c) Anterior guidance loading; d) Fixation of the jaw.

Table I - Mechanical properties of materials

\begin{tabular}{|c|c|c|}
\hline Material & $\begin{array}{c}\text { Elastic modulus } \\
(\mathbf{M P a})\end{array}$ & \begin{tabular}{c} 
Poisson Ratio \\
\hline Medullary bone[21]
\end{tabular} \\
\hline Cortical bone[21] & 1.370 & 0.31 \\
\hline Acrylic resin[22] & 35.400 & 0.3 \\
\hline Soft tissue[22] & 0.68 & 0.35 \\
\hline
\end{tabular}

\section{Post-processing}

The required results were in Maximum principal stress (MPa) to verify the tensile zones in the total prosthesis base, microstrain to verify possible areas of bone remodeling and total displacement $(\mathrm{mm})$ to evaluate the retention and stability of the set. The numerical results were converted into colorimetric maps and arranged according to corresponding scales. 


\section{RESULTS}

The results regarding the maximum principal stress and prosthesis displacement tests were directly proportional to the fibromucosa height, except for bone microstrain. The stress results (Figure 3) showed higher loading for anterior guidance, unilateral and bilateral posterior loading, respectively, with maximum principal stress (MPa) ranged from 1.7 to $8.8 \mathrm{MPa}$. Hot colors mean higher stress values, while cold colors indicate lower stress values. Positive values indicate areas that were subjected to tensile stress and possible failure regions. In the analysis of the bone microstrain (Figure 4), only the unilateral posterior loading showed an increase in the bone response and the microstrain ranged from 0.00017 to 0.00042 $\mathrm{mm}$. The strain map was very similar between the models, showing an homogeneous distribution in the bone surface. The lower movement was found in the bilateral posterior loading in the total prosthesis displacement (Figure 5). The displacement ranged from 0.54 to $1 \mathrm{~mm}$ for anterior guidance and unilateral posterior loading. The quantitative value for each analysis criteria was plotted in Table II for direct comparison between the groups.
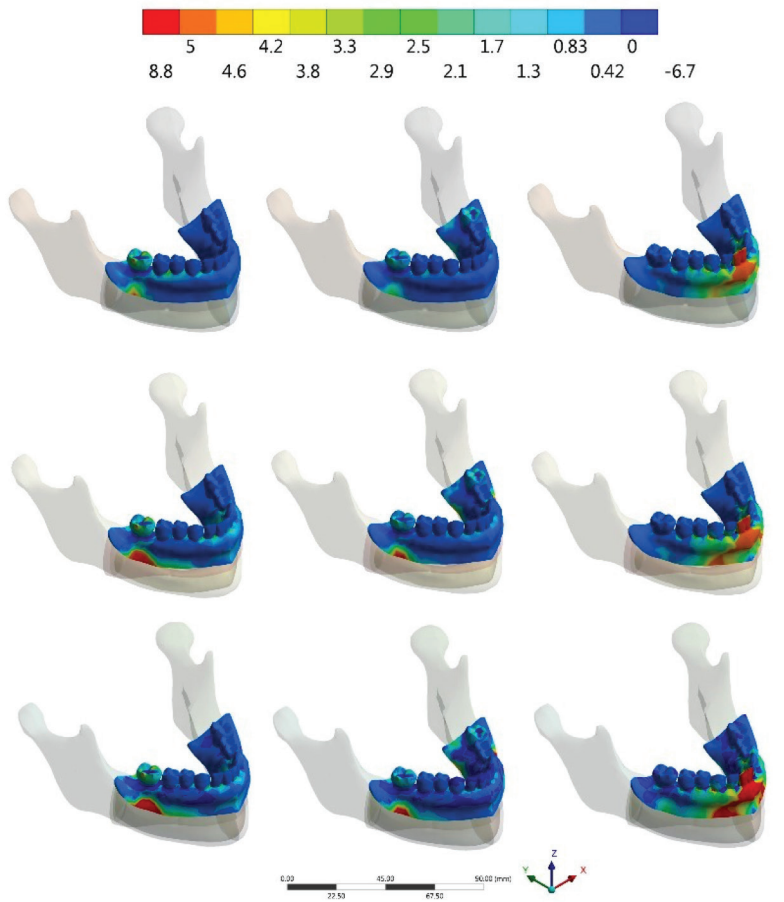

Figure 3 - Maximum principal stress distribution according to the soft tissue height (From left to right: thick, medium and thin) and different loads (Columns): a) Unilateral posterior loading; b) Bilateral posterior loading; c) Anterior guidance loading.

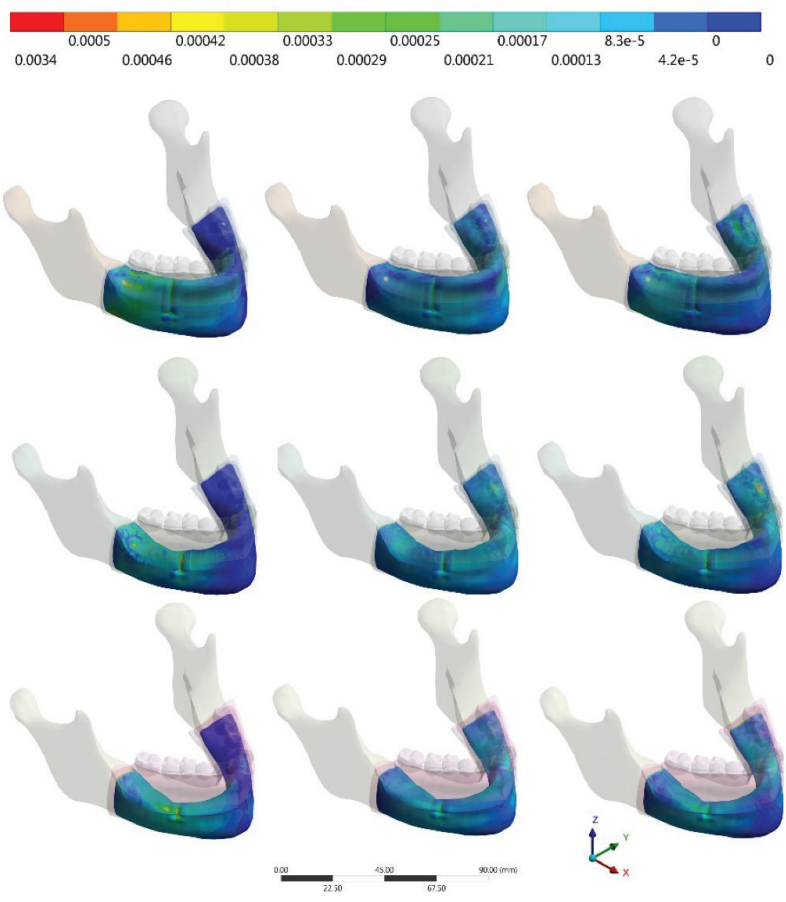

Figure 4 - Bone microstrain according to the soft tissue height (From left to right: thick, medium and thin) and different loads (Columns): a) Unilateral posterior loading; b) Bilateral posterior loading; c) Anterior guidance loading.
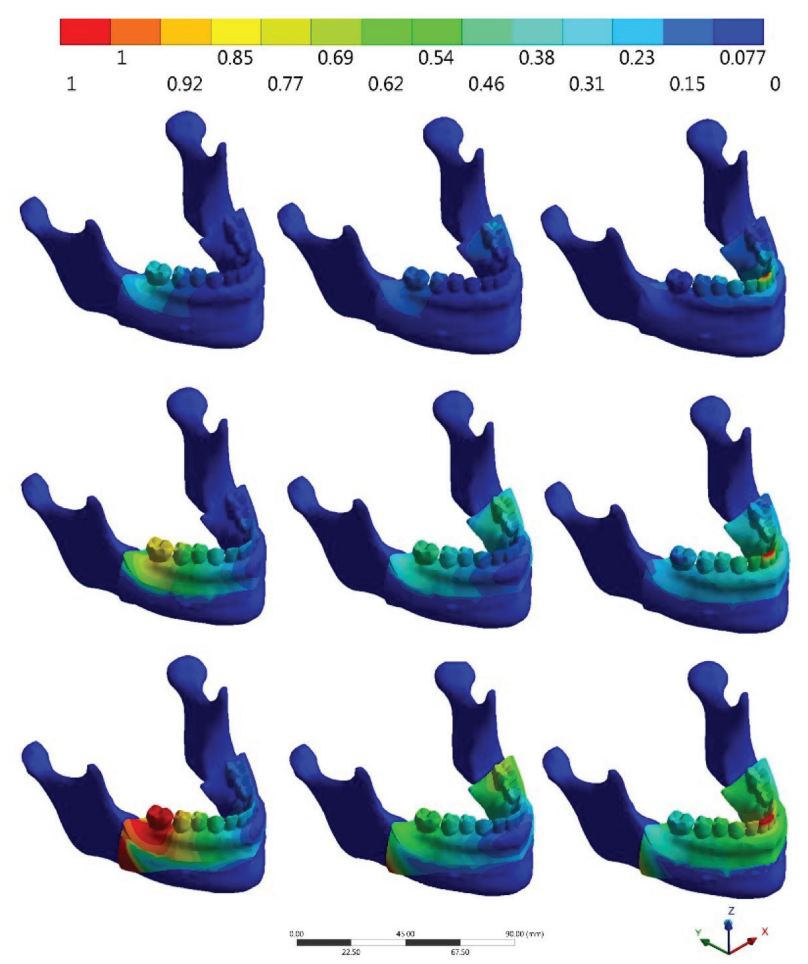

Figure 5 - Total displacement according to soft tissue height (From left to right: thick, medium and thin) and different loads (Columns): a) Unilateral posterior loading; b) Bilateral posterior loading; c) Anterior guidance loading. 
Table II - Contact point, Load application, Fibromucosa height, Maximum and mean of tensile stress (MPa), Stress concentration, Displacement $(\mathrm{mm})$ and Microstrain $(\mathrm{mm} / \mathrm{mm})$

\begin{tabular}{|c|c|c|c|c|c|c|c|}
\hline $\begin{array}{l}\text { Contact } \\
\text { simulation }\end{array}$ & Load Application & $\begin{array}{c}\text { Fibromucosa } \\
\text { height }\end{array}$ & $\begin{array}{c}\text { Maximum } \\
\text { Tensile Stress } \\
\text { atProsthesis } \\
\text { Base }\end{array}$ & $\begin{array}{c}\text { Mean of } \\
\text { Tensile stress } \\
\text { atProsthesis } \\
\text { Base }\end{array}$ & $\begin{array}{c}\text { Stress } \\
\text { concentration } \\
\text { (Peak/ Mean) }\end{array}$ & $\begin{array}{l}\text { Displacement } \\
\text { during } \\
\text { masticatory } \\
\text { load }\end{array}$ & $\begin{array}{c}\text { Bone } \\
\text { Microstrain }\end{array}$ \\
\hline \multirow{3}{*}{ Anterior Guide } & \multirow{3}{*}{$\begin{array}{l}\text { Incisal face of inferior } \\
\text { central incisors at } 45^{\circ}\end{array}$} & Thick & 8.17 & 4.58 & 1.78 & 0.49 & 247 \\
\hline & & Medium & 8.28 & 4.64 & 1.78 & 0.38 & 221 \\
\hline & & Thin & 9.81 & 7.05 & 1.39 & 0.26 & 224 \\
\hline \multirow{3}{*}{ Unilateral posterior } & \multirow{3}{*}{$\begin{array}{l}\text { Occlusal face of right } \\
\text { mandibular first molar } \\
\text { at } 90^{\circ}\end{array}$} & Thick & 8.40 & 6.15 & 1.36 & 0.89 & 294 \\
\hline & & Medium & 8.81 & 6.26 & 1.40 & 0.77 & 290 \\
\hline & & Thin & 8.83 & 7.34 & 1.20 & 0.55 & 293 \\
\hline \multirow{3}{*}{ Bilateral posterior } & \multirow{3}{*}{$\begin{array}{l}\text { Occlusal face of both } \\
\text { mandibular first molar } \\
\text { at } 90^{\circ}\end{array}$} & Thick & 5.51 & 3.76 & 1.46 & 0.74 & 217 \\
\hline & & Medium & 8.24 & 5.60 & 1.47 & 0.58 & 221 \\
\hline & & Thin & 8.80 & 5.78 & 1.52 & 0.23 & 232 \\
\hline
\end{tabular}

\section{DISCUSSION}

The fibromucosa height and the loading influenced the stress distribution, so the null hypothesis was rejected. In some studies, patients who received a mandibular total prosthesis felt discomfort because of their poor retention and stability [5,20-22]. Chen et al. [23] performed a systematic review and defined that the greater the fibromucosa thickness, the smaller the exerted masticatory force and the greater the microstrain resistance for the dental prosthesis. In turn, Sadr et al. [24] observed that the bilateral balanced loading generated less masticatory stress, thus corroborating the present results. Finally, the prosthesis displacement during bilateral posterior loading was more satisfactory compared to unilateral occlusion and anterior guidance, which means greater retention and stability to the prosthesis.

Using FEA for stress analysis serves as a parameter for researchers and dental surgeons to evaluate the mechanical response of the total prosthesis, without the need for laboratory and clinical studies. FEA helps to perfectly evaluate the retention and stability of the prosthesis in comparison with mechanical tests, in which researchers submit the patient with a mucosupported prosthesis to tactile sensitivity tests [5,14]. Limpuangthip et al. [5] analyzed the retention and stability of the prosthesis through the masticatory efficiency reported by the population with total denture and observed that the masticatory capacity is directly related to the retention and stability of the prosthesis.

Several researchers in dentistry have been using FEA to evaluate total prosthesis stresses, such as Nejatidanesh et al. [25] which evaluated the influence of muscle cut-offs on the stress concentration in the total prosthesis [25], the stress in the labial frenulum region [26], and the stabilization of the lower total prosthesis [27-29].

The choice of the denture base material also influences the stress on total dentures, and more rigid materials should be chosen (such as, thermally activated acrylic resins) to obtain better muscle balance [30-31]. Thus, the simulated material in the present model was a suitable material and used for making complete dentures.

In the present study, it was observed that the incidence of masticatory loads in the anterior region promotes higher stress concentration in comparison to the unilateral and bilateral loading, corroborating with Lima et al. [19]. Although tensile stress values do not exceed $9 \mathrm{MPa}$, meaning that it does not represent 
mechanical fracture during mastication. The study of Alsrouji et al., [32] analyzed the bone resorption of conventional total and overdenture prostheses, and observed that the stress was higher in the overdenture prosthesis.

In turn, the study of Ogawa et al. [14] analyzed the retention force of muco-supported prostheses in three distinct regions, advocating the use of in silico method for retention force tests. In spite of this wide use of theoretical analyzes for evaluating total prostheses, the results of the present study should be carefully extrapolated, since the variation in temperature and $\mathrm{pH}$, biofilm, diet, hygiene and prosthesis weight [33] were not simulated and may influence the results found in this investigation.

\section{CONCLUSION}

The incidence of posterior bilateral loading, regardless of the fibromucosa height, reduces the total prosthesis displacement, promotes lower stress concentration in the prosthesis base and less bone microstrain, being the most suitable loading for mandibular total prosthesis. Furthermore, the highest bone microstrain magnitude were calculated in unilateral posterior loading.

\section{Acknowledgements}

None.

\section{Conflict of interest statement}

The authors affirm that there is no conflict of interest.

\section{REFERENCES}

1. Paniz G, Chierico A, Tomasi P,Cuel S. A technique for immediate occlusal implant loading of a completely edentulous mandible: a clinical report. J Prosthet Dent 2012; 107:221-6. doi: 10.1016/S0022-3913(12)60064-X.

2. Zhao K, Mai QQ, Wang XD, Yang W, Zhao L. Occlusal designs on mastigatory ability and patient satisfaction with complete denture: a systematic review. J Dent 2013; 41:1036-42. doi: 10.1016/j.jdent.2013.07.016.

3. Owen PC. Appropriatech: prosthodontics for the many, not just for the few. Int J Prosthodont 2004:17:261-2
4. Carlson GE, Omar R. The future of complete dentures in oral rehabilitation: a critical review. J Oral Rehabil 2010;37:143-56. doi: 10.1111/j.13652842.2009.02039.x

5. Limpuangthip N, Somkotra T, Arksornnukit M. Modified retention and stability criteria for complete denture wearers: a risk assessment tool for impaired masticatory ability and oral health-related quality of life. J Prosthodont Dent 2017;120:1-7. doi: 10.1016/j.prosdent.2017.09.010.

6. Sousa RM, Simamoto-Junior PC, Fernandes- Neto AJ, Sloten JV, Jaecques SV, Pessoa RS. Influence of conection types and implant number on the biomechanical behavior of mandibular full-arch rehabilitation. Int J Oral Maxillofac Implants 2016;31: 750-60. doi: 10.11607/jomi.4785.

7. Matsumaru Y. Influence of mandibular residual ridge resorption on objective masticatory measures of lingualized and fully bilateral balanced denture articulation. J Prosthodont Res 2010;54:110-8. doi: 10.1016/j.jpor.2009.11.008.

8. Kimoto S, Gunji A, Yamakawa A, Ajiro H, Kanno K, Shinomiya M, et al. Prospective clinical trial comparing linguarized occlusion to bilatera balanced occlusion in complete dentures: a pilot study. Int J Prosthodont 2006;19:103-9.

9. Lemos CAA, Verri FR, Gomes JML, Santiago Junior JF, Moraes SLD, Pellizzer EP.Bilateral balanced occlusion compared to other occlusal schemes in complete dentures: a systematic review. J Oral Rehabil 2018; 45:344-54. doi: 10.1111/joor.12607.

10. Peroz I, Leuenberg A, Haustein I, Lange LP.Comparison between balanced occlusion and canine guidance in complete denture wearers- a clinical, randomized trial. Quintessence Int 2003;34:607-12

11. Ogawa T, Sato Y, Kitagawa N, Nakatsu M. Relationship between retention forces and stress at the distal border in maxillary complete dentures: Measurement of retention forces and finite-element analysis in individual participants. J Prosthodont Dent 2017; 117:524-31. doi: 10.1016/j. prosdent.2016.08.011.

12. Paulino MR, Alves LR, Gurgel BC, Calderon PS. Simplified versus traditional techniques for complete denture fabrication: a systematic review. JProsthet Dent 2015;113 (1):12-6. doi: 10.1016/j.prosdent.2014.08.004.

13. Ceruti P,Mobilio N, Bellia E, Borracchini A, Catapano S, Gassino G. Simplified edentulous treatment: a multicenter randomized controlled trial to evaluate the timing and clinical outcomes of the technique. J Prosthet Dent 2017;118(4):462-7.

14. Cheng YY, Cheung WL, Chow TW. Strain analysis of maxillary complete denture with three-dimensional finit element method. J Prosthodont Dent 2010;103:309-18. doi:101016/j.prosdent.2017.01.024

15. Ramakrishnan H, Singh RG. Three dimensional finite element analysis of the stress distribution pattern in the design modifications of $\mathrm{U}$ - shaped palatal major connector. Indian J Dent Res 2010;21:506-11. doi: 10.4103/09709290.74219 .

16. Lima JB, Orsi IA, Borie E, Lima JH, Noritomi PH. Analysis of stress on mucosa and basal bone underlying complete dentures with different reliner material thicknesses: a three-dimensional finite element study. J Oral Rehabil 2013;40:763-73. doi: 10.1111/joor.12086.

17. Borges Radaelli MT, Idogava HT, Spazzin A0, Noritomi PY, Boscato N . Parafunctional loading and occlusal device on stress distribution around implants: A 3D finite element analysis. J Prosthet Dent 2018;120:565-72. doi: 10.1016/j.prosdent.2017.12.023.

18. Schwitalla AD, Emara-Abou M, Spintig T, Lackmann J, Müller WD Finite element analysis of the biomechanical effects of PEEK dental implants on the peri-implant bone. J Biomech 2015;48:1-7. doi: 10.1016/j. jbiomech.2014.11.017. 
19. Amaral CF, Gomes RS, Garcia RCMR, Del Bel Cury AA. Stress distribution of single-implant-retained overdenture reinforced with a framework: $A$ finite element analysis study. J Prosthodont Dent 2017;119:791-6. doi:101016/j. prosdent.2017.07.016.

20. Fenlon MR, Sherriff M. Investigation of new complete denture quality and patients satisfaction with and use of dentures after two years. J Dent 2004:32:327-33

21. Yamaga E, Sato Y, Minakuchi S. A structural equation model relating oral condition, denture quality, chewing ability, satisfaction and oral healtyrelated quality of life in complete denture wearers. JDent 2013:41:710-7. doi: 10.1016/j.jdent.2013.05.015

22. Cerutti-Kopplin D, Enami E, Hilgert JB, Hugo FN, Rivaldo E, Padilha DMP. Predictors of satisfaction with dentures in a cohort of individuals wearing old dentures: functional quality or patient-reported measures? J Prosthodont 2017;26:196-200. doi: 10.1111/jopr.12383.

23. Chen J, Ahmad R, Li W, Swain M, Li Q. Biomechanics of oral mucosa. JR Soc Interface 2015;12:1-20. doi: 10.1098/rsif.2015.0325.

24. Sadr K, Alipour J, Heidary F. Finite element analysis of soft-lined mandibular complete denture and its supporting structures. J Dent Res Dent Clin Dent Prospects 2012;6:37-41

25. Nejatidanesh F, Peimannia E, Savabi 0 . Effect of labial frenum notch size and palatal vault depth on stress concentration in a maxillary complete denture: a finite element study. J Contemp Dent Pract. 2009 May 1;10(3):59-66

26. Zunbuloglu E. Stress analysis of a complete maxillary denture under various drop impact conditions: a 3D finite element study. Comput Methods Biomech Biomed Engin 2015;18:1543-54. doi: 10.1080/10255842.2014.927446.
27. Zmudzki J, Chladek G, Malara P.Use of finite element analysis for the assessment of biomechanical factors related to pain sensation beneath complete dentures during mastigation. J Prost Dent 2018;120:934-41. doi: 0.1016/j.prosdent.2018.02.002.

28. Zmudzki J, Chladek G, Krawczyk C. Relevance of tongue force on mandibular denture stabilization during mastication. J Prosthodont 2019;28:27-33. doi: 10.1111/jopr.12719.

29. Zmudzki J, Chladek G, Kasperski J. The influence of a complete lower denture destabilization on the pressure of the mucous membrane foundation. Acta Bioeng Biomech 2012;14:67-73.

30. Shrivastava R, Chaturvedi S, Verma AK, Ali M, Nagendra A, Chatuverdi M. Stress distribution under commercial denture liners- $A$ finite element and clinical analysis. J Clin Diag Res 2016;10:14-8. doi:10.7860/ JCDR/2016/21466.9027.

31. El-Zawahry MM, El-Ragi AA, El- Anwar MI, Ibraheen EM. The biomechanical effect on different denture base materials on the articular disc in complete denture wearers: a finite element analysis. J Med Sci 2015;3:455-61. doi: 10.3889/oamims.2015.074.

32. Alsrouji MS, Ahmad R, Razak NHA, Shuib S, Kuntjoro W, Baba NZ. Premaxilla stress distribution and bone resorption induced by implant overdenture and conventional denture. J Prosthodont 2019;28:764-70. doi:10.1111/jopr.12954.

33. Tribst JPM, Dal Piva AMO, Borges ALS, Rodrigues VA, Bottino MA, Kleverlaan CJ. Does the prosthesis weight matter? 3D finite element analysis of a fixed implant-supported prosthesis at different weights and implant numbers. J Adv Prosthodont. 2020;12(2):67-74.

\section{Cristiane Mayumi Inagati}

(Corresponding address)

São Paulo State University (Unesp), Institute of Science and Technology, São José dos Campos, Department of Dental Materials and Prosthodontics

Email: cristiane.inagati@unesp.br

Date submitted: 2020 Apr 08

Accept submission: 2020 Sep 08 